\title{
China's Exchange Rate Policy: The Case For Greater Flexibility*
}

\author{
Ivan Roberts** \\ Reserve Bank of Australia \\ Rod Tyers \\ School of Economics \\ Faculty of Economics and Commerce \\ Australian National University
}

September 2001

Corresponding author:

Professor Rod Tyers

School of Economics

Bldg 26, ANU

Canberra, ACT 0200

Australia

rod.tyers@anu.edu.au

Fax: 61-2-6125-5124

*Thanks are due to Meng Xin, Warwick McKibbin, Xiaolu Wang, Ben Smith, Graeme Wells and Yongzheng Yang for useful discussions on the topic of this paper. The bulk of this work was completed when Ivan Roberts was affiliated with the Faculty of Economics and Commerce at the Australian National University. The views expressed in this paper are those of the authors alone and in no way represent those of the Reserve Bank of Australia. 


\title{
China's Exchange Rate Policy: The Case For Greater Flexibility
}

\begin{abstract}
Since the Asian crisis, the merit of the Chinese government's de facto peg to the US dollar has been the subject of widening debate. This paper reviews the issues surrounding China's currency regime choice and assesses the case for greater flexibility. Reform era exchange rate policies are examined along with the performance of the economy during and since the Asian crisis. In the Chinese context the arguments for and against fixed exchange rates are then explained and assessed. Finally, an elemental comparative static macroeconomic model is used to examine the implications of domestic and external shocks under different exchange rate regimes and with differing degrees of capital mobility. The results support the view that more flexibility would be beneficial to China and that this benefit can be expected to increase as capital mobility increases.
\end{abstract}

\section{Introduction}

Over the past two years Chinese authorities have met with pressure from the IMF to adopt a more flexible regime for the renminbi (RMB). ${ }^{1}$ Despite the government's apparent decision to maintain its de facto peg to the dollar at least in the short term, the optimality of this policy is increasingly being questioned both at home and abroad (Zhang and Shen, 2000; Yang and Tyers, 2000). While the People's Bank of China (PBC) has stressed repeatedly that the RMB shall remain stable, China has no official exchange rate target and classifies its currency regime as a 'managed float'.

Policymakers thus have considerable leeway in their management of China's currency and are not committed to maintaining the peg indefinitely. ${ }^{2}$ Indeed, the stabilisation of the East Asian region that has occurred since the currency crisis suggests that the time may be ripe for a fundamental change in China's exchange rate policy.

In this paper we take stock of the issues surrounding China's currency regime choice and assess the case for greater flexibility. Section 2 reviews China's reform era exchange rate policy and the economy's performance under a pegged exchange rate

\footnotetext{
${ }^{1}$ The Australian Financial Review (AFR), 27 June 2000; IMF, $2001 \mathrm{~b}$.

2 The PBC has affirmed that it will work towards enhancing the flexibility of the RMB after China's WTO entry, but that the currency will remain 'stable' for another five years (see reports on the government website at http://ce.cei.gov.cn). While the currency has been allowed to trade outside its narrow range of Y8.277/US\$ to Y8.280/US\$ more than seventy times over the past fifteen months (although only twice outside the weak end), the band has been maintained quite strictly since the crisis.
} 
during and since the Asian crisis. Section 3 discusses the arguments for and against fixed exchange rates, focusing on the nominal anchor argument. Section 4 assesses these arguments in the Chinese context, paying particular attention to the implications a nominal peg will have for macroeconomic adjustment as China's capital markets become globally integrated. In Section 5 a simple comparative static model of the Chinese economy is described and, in Section 6, model simulations are presented for several external and domestic shocks under varying degrees of capital mobility. The simulation experiments support the idea that China might benefit from a flexible currency regime, and that the case for flexible exchange rates will strengthen as capital mobility increases. Section 7 investigates possible extensions of the foregoing analysis and, finally, Section 8 offers conclusions.

\section{Background}

Between 1981 and 1986 the RMB was pegged to a basket of internationally traded currencies weighted according to their importance in China's external transactions. Since then, although the authorities have classified the currency regime as a 'managed float', in reality exchange rate policy has not been uniform. From 1986 to 1994 three different rates were effective at the same time: the 'official' rate (an oft-adjusted peg to the US dollar); 'swap' market rates (unofficial floating rates which the central bank occasionally adjusted through market intervention); and the 'effective' exchange rates actually faced by exporters (weighted averages of official and unofficial rates). ${ }^{3}$ The apparent overvaluation of the official exchange rate during the 1980s, at least relative to the market-based exchange rates, was a source of concern to policymakers who recognised it as a tax on exporters. Committed to improving the trade balance, the authorities intervened in the swap market and, from 1989, repeatedly devalued the official rate, eventually unifying the official and swap market exchange rates at the prevailing swap rate in 1994.

The hallmark of exchange rate policy in the 1990s was the authorities' adherence to a 'real targets' approach (described by Corden, 1993), whereby the exchange rate was

\footnotetext{
${ }^{3}$ This arrangement of multiple exchange rates was a by-product of the foreign exchange retention quota system (see Mehran, et al. 1996).
} 
targeted at the 'domestic cost of earning a unit of foreign exchange through exporting'. 4 However, the onset of the Asian crisis in 1997 compelled the authorities to abandon this approach in favour of a rigid peg to the US dollar, a policy that has persisted to the present.

China's performance during the Asian currency crisis has been well documented (Song, 1998, Fernald and Babson, 2000; Yang and Tyers; 2000). Initially to protect Hong Kong's currency board, the Chinese leadership responded by fixing nominal parity with the US dollar in 1997. Growing regional instability compelled the authorities to persevere with the peg, however, and China's decision not to devalue was widely applauded at the time for preventing a further round of competitive devaluations. ${ }^{5}$ In fact, substantial foreign exchange reserves, combined with capital controls that had prevented excessive short-term external debt accumulation and a ban on futures trading in the RMB, shielded China from the worst effects of the crisis and could possibly have done so even with a devaluation in 1998.

As it was, the economy did not escape the Asian crisis unscathed. Between 1997 and 1998 unsanctioned outflows on the capital account nearly doubled despite the capital controls, reflecting a rise in perceived 'country risk' ${ }^{6}$ Foreign direct investment (FDI) declined, and the real exchange rate appreciated relative to China's neighbours, damaging export competitiveness. ${ }^{7}$ At the same time, widespread layoffs resulting from stateowned enterprise (SOE) reforms contributed to rising unemployment, which, combined with other reforms reducing the state provision of welfare services, encouraged households to substitute saving for consumption. ${ }^{8}$ Falling export growth and FDI on one hand, and a rise in the marginal propensity to save on the other, contracted aggregate demand and deflated the price level. ${ }^{9}$ Decelerating prices tended to increase real interest

\footnotetext{
${ }^{4}$ See Zhang (1999).

5 This applause came from, among others, Dornbusch (1999), Chen (1999) and Ni (1999). One substantial proponent of the dollar peg was the US government, which feared a devaluation of the RMB would worsen the bilateral trade imbalance with China and raise protectionist pressures in the build-up to the 2000 election. Insiders suggest that one reward for the maintenance of the peg was US agreement on China's accession to the WTO.

${ }^{6}$ See Tyers and Yang (2000), especially their Table 1. Fernald and Babson (2000) estimate that the risk premium on foreign investment in China rose by 250 basis points between 1996 and 1998.

See Table 1 and Figure 1.

${ }^{8}$ See Tyers and Yang (2000), and Huang (1999).

${ }^{9}$ See Table 1.
} 
rates and real wage growth, contributing further to the growth slow-down.

In 1998, official statistics report a slowdown of GDP growth from 9.6\% in 1996 to $7.8 \%{ }^{10}$ The PBC attempted to boost investment by lowering administered nominal interest rates five times over the 1996-1998 period, leaving the defense of the exchange rate to the management of its considerable foreign reserves. Yet this failed to offset the rise in real interest rates associated with price deflation and an associated contraction in bank lending to the private sector. Since the monetary stance was de facto restrictive, the most expansionary policy response to the crisis was an increase in government spending of around $17 \%$ in $1998 .^{11}$

It has been argued that if the PBC had floated the RMB and allowed it to depreciate, rather than pegging the currency, some of the damage to exports and FDI might have been avoided. Tyers and Yang (2000) employed global comparative-static general equilibrium analysis to simulate the principal shocks to the Chinese economy during the Asian crisis under fixed and floating currency regimes. They found that a depreciation during the crisis could have prevented losses of about 4\% of GDP per year, suggesting that despite its regional benefit the domestic cost of the policy was considerable.

China has shown signs of recovery since 1998. Exports surged in 2000, retail sales accelerated, suggesting increased consumer confidence, and positive consumer price inflation re-emerged after virtually continuous deflation since October 1997 (see Table 1). ${ }^{12}$ It is in this climate that observers of China's exchange rate policy, including the IMF, have begun to question the appropriateness of an ongoing peg to the US dollar. Arguably the biggest obstacle to a more flexible regime for the RMB after 1997 was the fear of sparking another wave of competitive devaluations around the region, thus worsening the crisis. However, in the current climate, there is much less justification

\footnotetext{
${ }^{10}$ See Table 1. One possible explanation for the retarded growth is that, given China's highly regulated labour market, nominal wages were sticky downwards (explaining the recorded rise in real wages), which prevented output from expanding at a higher rate (see Tyers and Yang, 2000, who also consider other possibilities).

${ }^{11}$ See Table 1 . The increase in government expenditure amounted to a rise of about $1 \%$ of GDP in the 1996-98 period.

${ }^{12}$ The Asian Wall Street Journal, various issues. Although increased retail sales provide some support for the hypothesis of increased consumer confidence, the figures should be treated with scepticism, since policymakers have employed various methods (including extending national holidays throughout 2000) to boost recorded sales. See $A F R, 7-8$ October 2000.
} 
for a US dollar peg, since competitive devaluation fears have subsided since 1998 as the region has stabilised. The transitions from current account deficit to surplus in Indonesia, Malaysia, the Philippines, Thailand and Korea, necessitated by the crisis, have been sustained, short term debt has declined since 1997, international reserves have grown, and since the crisis-induced initial correction, real effective exchange rates are stable or appreciating. Some crisis-affected countries have seen revived capital inflows (an indication of resurfacing investor confidence), and all have experienced higher GDP growth. $^{13}$

While financial and corporate restructuring are still priorities for the crisisaffected economies, improvement of macroeconomic fundamentals on the one hand and exchange rate re-alignments on the other have made many currencies less vulnerable to speculative attacks. At least for the near future, if China adopted a flexible exchange rate and the RMB subsequently depreciated, it would not probably not affect the region too adversely.

A corollary of improved regional stability is the opportunity for change that it affords. China's policymakers face an important choice, with serious implications for macroeconomic policy, now and in the future. Thus the present exchange rate policy demands a critical assessment. We first review some of the key arguments for and against fixed exchange rates that appear in the literature.

\footnotetext{
${ }^{13}$ IMF (2000a, 2000b, 2001a).
} 


\section{Exchange Rate Regime Choice: Theoretical Perspectives and Policy Alternatives}

There are four basic arguments for maintaining a fixed exchange rate. First, a peg to the currency of a low-inflation country can contribute directly to price stability by fixing the inflation rate for goods traded with that country. Second, a truly credible peg can eliminate exchange rate risk and thus avoid risk-associated damage to trade and FDI flows (which may be discouraged by excessive exchange rate volatility when adequate hedging instruments are scarce). Third, if the peg is credible it can provide a nominal anchor for inflationary expectations by committing the monetary authority to a transparent policy rule, and thereby curtail the scope for discretion. Fourth, if one country together with another country or group of countries constitutes an optimum currency area (OCA), then by definition a fixed exchange rate or, more drastically, a currency union, is the appropriate policy for the country concerned. ${ }^{14}$ As the first two arguments are associated with the theory of optimum currency areas, they will be treated under that heading.

The nominal anchor argument is based on the idea that discretionary monetary policy can have an inflationary bias, and that targeting the currency of a stable, lowinflation country may prevent individuals from building that bias into their price expectations, thus contributing to price stability. The implications of a nominal anchor policy are clear. When capital is relatively mobile between countries, a nominal peg to the US dollar, for example, amounts to targeting the US interest rate, since a widening of the domestic-foreign interest differential would entail immediate flows on the capital account, putting pressure on the value of the currency. In effect, a nominal anchor 'imports' monetary discipline and low inflation by requiring that the central bank follow the monetary policy of another country.

An obvious criticism of the nominal anchor approach is that pegging the domestic interest rate to that of a foreign country is inappropriate if the shocks to which foreign monetary policy responds differ from those faced by the pegging country. By relinquishing control of the money supply, the authorities jeopardise their ability to respond to external and domestic shocks with monetary stabilisation policy. ${ }^{15}$ Although

\footnotetext{
${ }^{14}$ See Frankel (2000) and Mishkin (1999).

${ }^{15}$ See Obstfeld and Rogoff (1995a).
} 
standard Mundell-Fleming-type models predict that the efficacy of fiscal policy is enhanced when the exchange rate is fixed, fiscal policy, subject as it is to lengthy administrative and transmission lags, as a policy tool may be inferior to monetary policy.

Moreover, a pegged exchange rate will only anchor nominal expectations if it is credible. Accountability is a problem for many central banks, particularly in developing countries, and as Mishkin (1999) notes, fixing the exchange rate may make matters worse by concealing a key indicator of the stance of monetary policy (the floating nominal exchange rate). Although a nominal anchor may be what is needed to reduce inflation in a country with a record of price instability, obtaining an appropriate commitment technology remains the real challenge.

Of course, from the currency speculator's perspective it questionable that any pegged regime is truly credible. As Obstfeld and Rogoff (1995a) observe, when capital mobility is high, government pledges to foil a large-scale speculative attack are seldom credible even when there is no danger of a balance of payments crisis. Speculators know that the harm caused to domestic investment and bank solvency by interest rate hikes employed in defence of fixed parity often has political costs severe enough to make the defence unsustainable. Thus adopting a pegged currency regime may augment the risk of speculative attacks on the currency.

A possible antidote to the credibility problem is to adopt a currency board arrangement, in which the exchange rate is fixed by law and all currency issued is backed by foreign reserves, thus eliminating the inflation tax as a potential policy tool. However, currency boards are unlikely to anchor expectations successfully in countries where the rule of law is not respected or authority cannot be delegated, since it is the binding legal discipline imposed upon the monetary authority that makes the commitment credible. ${ }^{16}$

The natural alternative to any kind of fixed regime, of course, is a floating exchange rate, the classic advantage of which is that it helps insulate real activity from external shocks by appreciating automatically when the shock is beneficial and depreciating when it is adverse. Friedman's (1953) point that exchange rates adjust much faster than domestic prices and quantities, making this insulation all the more valuable, remains a potent one. In addition, a flexible policy gives the monetary authority the

\footnotetext{
${ }^{16}$ Frankel (2000); Cottarelli and Giannini (1997).
} 
independence to respond quickly to domestic and external shocks as required, rather than tying domestic policy to monetary developments abroad.

Empirical evidence on the performance of nominal anchor currency regimes has generally been inconclusive, partly reflecting the sheer diversity of experiences, and partly because of the methodological difficulties that plague econometric analyses of the issue. ${ }^{17}$ However most authors agree that fixed and flexible regimes can work in practice, depending on (a) the strength of policymakers' commitment to macroeconomic stability, and $(b)$ the specific characteristics of the country concerned. ${ }^{18}$ The theory of optimum currency areas (OCAs) addresses this second issue. Its focus is on the country characteristics that would make fixed exchange rates an attractive option. ${ }^{19}$

Three commonly cited OCA criteria are: $(i)$ openness (proxied by the trade ratio), (ii) relative size (in proportion to a trading partner), and (iii) the extent to which output shocks are correlated. Openness matters $(a)$ because the inflation rate of a country whose ratio of trade to real GDP is high may be seriously affected by exchange rate-led variability in the prices of tradeables, and $(b)$, because exchange rate volatility may magnify currency risk, damaging trade flows. Thus there is a rationale for a peg to avoid the uncertainty of flexible exchange rates. In addition, it may be appropriate for a small country that is closely integrated (in terms of trade and capital flows) with a large trading partner, and faces similar shocks to income, to consider monetary integration with that partner (either by fixing the exchange rate, or entering into a monetary union).

The discussion so far has focused on a simple 'fixed' versus 'flexible' dichotomy. In reality there is a continuum of possible exchange rate regimes. Apart from currency unions, currency boards, single-currency pegs and flexible (floating or managed floating) exchange rates, a variety of intermediate regimes exist, including basket pegs, crawling pegs and crawling bands. ${ }^{20}$ Nonetheless, since China, unlike many Latin American developing countries, does not have a history of persistent high inflation or

\footnotetext{
${ }^{17}$ See Edwards and Savastano (1999) for a survey. They argue that definitional problems (the failure to distinguish between de jure and de facto regimes), and the phenomenon of 'survival bias' (that only successful peggers are included in the 'fixed exchange rate' category), have damaged the persuasiveness of many cross-country studies.

${ }^{18}$ See Edwards and Savastano (1999). This is basically the case put by Little, et al. (1995) for developing countries (see, in particular, chapter 5).

${ }^{19}$ Mundell (1961), McKinnon (1963), Kenen (1969); surveyed by Ishiyama (1975).

${ }^{20}$ A taxonomy of these is given in Edwards and Savastano (1999).
} 
hyperinflation, several regimes (especially the 'crawling' varieties designed to engineer a gradual recovery from very high inflation) are not relevant policy options. Basket pegs can be used to target foreign exchange earnings cost, as China did up to the mid-1990s, and are often considered appropriate for export-oriented Asian nations. ${ }^{21}$ A full assessment of the costs and benefits of basket peg regimes is beyond our scope, but it is worth noting here that insofar as the basket weights are usually kept secret, there is room for discretion behind the announced policy. Nonetheless, a genuinely rigid basket peg may paralyse monetary policy as seriously as a nominal peg. ${ }^{22}$

\section{China's Choice of Exchange Rate Regime}

Here we place the four arguments discussed in the previous section in the Chinese context. A key issue is whether the US dollar peg directly influences price stability in China. The answer depends in part on the extent of Sino-US trade, the importance of China's other trading partners, and on the specific goods that are traded with particular partners. While a stable US dollar exchange rate may stabilise the prices of some tradeable goods, other bilateral rates could be quite volatile, potentially contributing to price instability. ${ }^{23}$ If trade with the US constituted the bulk of China's trade, a fixed exchange rate might exert a powerful stabilising effect on the price level. It is debatable, however, that the US is even China's most important trading partner. Figures 1 and 2 graph the percentage export and import shares in China's trade for Japan and the US (China's two largest trading partners). Although the US has recently overtaken Japan in China's export market, Japan now dominates as an import supplier; clearly both are close contenders. Thus it is not obvious that the 'direct' effect augments the case for China's peg to the dollar.

The extent to which trade flows can be protected by the risk-reducing properties of a fixed exchange rate is another difficult question. There is reason to think that, since a forward exchange market is not currently permitted in China, the gains could be substantial, as traders would have no means to insure against foreign exchange risk under

\footnotetext{
${ }^{21}$ See Benassy-Quere (1996) and Frankel (2000).

${ }^{22}$ Ibid.

${ }^{23}$ As Zhang and Shen (2000) observe, bilateral nominal exchange rates against the currencies of Japan, France and Germany (all substantial trading partners) were comparatively volatile during the Asian crisis.
} 
a floating exchange rate. Until China liberalises the capital account, this argument for fixed exchange rates will retain some plausibility. However, it is usually argued that the currency risk premium will only be eliminated completely if the exchange rate is irrevocably fixed. ${ }^{24}$ As discussed below, China's currency is not credibly fixed, which would tend to weaken this argument.

One argument for preserving the peg is that a stable US dollar exchange rate is valuable to China as a nominal anchor. The earlier discussion, however, would suggest that the benefit is probably small. The main reason is that in its present form China's peg to the dollar is not credible, in part because it is a de facto peg - there is no associated public commitment. The fact that 'devaluation fears' have appeared regularly in the financial press, and that policymakers have had to promise repeatedly that the RMB will remain 'stable', reveals some of the insecurity with which market participants view the policy. ${ }^{25}$ Moreover, as an anchor for inflationary expectations, the policy can hardly be credible while China's capital controls extend the authorities space for monetary discretion. Even if the authorities made the peg official (instead of quasi-official) by announcing buying and selling rates for the currency, it is unlikely that this would improve the policy's credibility, given $(i)$ the opaque nature of the policymaking process, (ii) the PBC's nearly complete subordination to political authority, and (iii) its lack of financial accountability.

Adopting a currency board in China, even if it were feasible, would not improve matters. As Frankel (2000) observes, a currency board must be completely separated from political authority if it is to be successful. While the current authoritarian leadership remains in power, economic agents are unlikely to place much faith in an institution whose authority in setting monetary policy supposedly overrides that of the Communist Party itself. ${ }^{26}$

While the fact that China's trade is closely integrated with neighbours such as Japan and Korea might suggest a regional currency union as a natural alternative to the

\footnotetext{
${ }^{24}$ Obstfeld and Rogoff (1995a).

${ }^{25}$ See AWSJ and Chinaonline (available at URL: http://www.chinaonline.com), in which the views of market analysts and participants regularly appear.

${ }^{26}$ On the question of monetary policy credibility, Cottarelli and Giannini (1997: 16) note that "policymakers operating under a regime of political dictatorship... might find it hard to precommit themselves even if they wanted to."
} 
US dollar peg, this is unlikely to happen any time soon. Indeed, as Benassy-Quere (1996) has noted, Asian nations have for both economic and cultural reasons preferred US dollar pegs to links with the yen (which being one of the world's most traded currencies, is an obvious choice). The fragility of the Japanese economy over the past decade (and its continuing decline) is one reason why a yen bloc seems unlikely in the near future. In addition, historical grievances relating, in part, to Japan's wartime activities would make monetary integration politically impossible for several Asian nations, including China.

Thus, we see reason to doubt the applicability to the Chinese case of many of the arguments against exchange rate flexibility considered in Section 2. Yet a compelling case for discarding the current policy in favour of a more flexible regime does exist and it relies on the link between exchange rates and macroeconomic policy. Although exchange rates were adjusted to improve the trade balance, until the mid-1990s the stance of fiscal and monetary policy remained largely insulated from these adjustments, owing to the non-convertibility of the currency and rigid exchange controls (Huang and $\mathrm{Li}$, 1996). Current account convertibility was achieved in 1996, but to date the RMB remains inconvertible on the capital account and subject to various restrictions. ${ }^{27}$ Although a date has not been set for making the RMB fully convertible, it appears to be high on the agenda and could well occur within the present decade. ${ }^{28}$ Already the authorities are considering opening China's RMB-priced A-share market (currently reserved for domestic investors) to overseas institutional investors. Despite the existing capital controls, unsanctioned capital outflows have risen dramatically since the mid1990s, particularly during the Asian crisis. This accords with the common perception that capital controls tend to become less effective over time. ${ }^{29}$

\footnotetext{
${ }^{27}$ China's capital controls include restrictions on futures trading of the RMB, foreign borrowing by Chinese enterprises, portfolio investment in China by foreigners and portfolio investment abroad by Chinese citizens.

${ }^{28}$ The PBC has announced that 'great progress' would be made towards this end in the next five years (China Economy News (July 20, 2000) [Chinese Government website], URL: http://www.ce.cei.gov.cn). ${ }^{29}$ According to estimates by Tyers and Yang (2000), unsanctioned capital outflows were US\$62.9 billion in 1998, compared to just US\$8.4 billion in 1994. More recent EIU estimates (presented in Table 1), suggest that the trend has not reversed. See AWSJ (editorial, 15-17 September 2000) and Mathieson and Rojas-Suarez (1993), especially chapter 3.
} 
Unlike the Latin American economies, where nominal anchor arguments are frequently applied, the People's Republic of China does not have a history of hyperinflation or even sustained high inflation. Moreover, it has employed monetary policy successfully to combat inflation when it appeared. Although the economy has experienced at least four inflationary episodes since 1978, in each case a combination of monetary tightening and administrative 'anti-inflation' campaigns succeeded in bringing prices down rapidly, apparently without severely retarding output growth. ${ }^{30}$

One crucial economic phenomenon facing China's policymakers now and in the near future is the rise of capital mobility. Another is interest rate liberalisation, which the PBC has pledged to implement fully over the next three years, starting with lending rates. ${ }^{31}$ As capital mobility increases and interest rates are liberalised, preserving the peg will ultimately mean abandoning any remaining monetary policy independence. There would be an argument for doing this if China, like Argentina, had proved incapable of discretion in its exploitation of monetary independence and was therefore forced to adopt a currency board. China's reform-era macroeconomic record suggests this is not the case. Indeed, monetary policy is the most powerful anti-inflation weapon possessed by the authorities. ${ }^{32}$ It can be argued that alternative nominal anchor targeting regimes associated with a floating exchange rate policy are, along with nominal pegs, also likely to suffer from the credibility problem. But it is clear that this only strengthens the case for making the choice of currency regime on other criteria, such as the value of monetary independence and the likely insulation from shocks offered by a floating exchange rate.

As interest rate determination is increasingly left to the market and capital controls are removed, maintaining a US dollar peg will effectively bind Chinese monetary policy to the US Federal Reserve's through interest parity. Since two countries as diverse as China and the US are likely to face different domestic and external macroeconomic shocks, this policy is clearly not in China's long term interest. Moreover, as capital mobility increases China's vulnerability to speculative attacks will rise. The commitment to defend the peg may lose all credibility with speculators if domestic or

\footnotetext{
${ }^{30}$ See Oppers (1997), whose econometric study uses official data. Inaccuracies in reported statistics may hide the full extent of China's sacrifice ratio.

${ }^{31}$ AWSJ, 6 September 2000. While the interbank rate is floating, at present loan and deposit rates fluctuate within narrow bands set by the central bank. See Mehran, et al. (1996).
} 
regional conditions deteriorate again, increasing the likelihood of attacks on the currency, even if China's large reserves are sufficient to avoid a balance of payments crisis. ${ }^{33}$ Finally, the rise of capital mobility will by definition increase the speed and magnitude of capital flows. If the floating nominal exchange rate is eliminated as a means of insulating the economy from external shocks, the domestic adjustment required to sustain the nominal peg must rise in proportion with capital mobility.

The case against maintaining the peg would be less convincing if China's (increasingly US dollar denominated) external debt were high, since this would increase the potential damage a fluctuating US dollar exchange rate could do to the domestic economy. However, compared to other developing countries, China's ratio of external debt to national income has been low during the 1990s. Indeed, China's 1991-7 average external debt to GNP ratio of $17.4 \%$ is less than half the developing country average of $37.1 \%$, and compares even more favourably to the Asian-crisis affected country average of $46.9 \% .{ }^{34}$ Hence debt concerns do not weaken the case for a more flexible exchange rate regime.

\footnotetext{
${ }^{32}$ Tax policy in China is both ineffective and inflexible (Fung, et. al., 2000).

33 It might be thought that China's authoritarian government was less constrained by the 'political costs' of defending a peg when capital is mobile, than those of more democratic countries. However, since the inception of economic reforms, the authorities have staked their political legitimacy on their ability to improve economic welfare. A perceived downturn in economic conditions is increasingly likely to fuel civil unrest, which the leadership always views with concern.

34 These figures come from the World Bank, 1999. The 'crisis countries' considered were Malaysia, Thailand, Indonesia, Korea and the Philippines.
} 


\section{An Elemental Open Economy Macroeconomic Model}

We illustrate the benefits of monetary policy independence as capital mobility increases by resort to a simple numerical macroeconomic model structured to resemble China's economy in 1996. Since capital immobility was identified in the previous section as one of the key distortions affecting the path of the Chinese macroeconomy, we use the model to focus on this issue. The formulation we use is comparative static and of the Mundell-Fleming type. In this comparative static world the price level is endogenous but continuous inflation is ruled out and so there is only one domestic interest rate. A length of run is considered over which investment does not alter the current physical capital stock.

The demand side:

Three markets are represented: that for a single consolidated asset ("bonds"), which offer a return of $r$ (alternatively called the "capital" or "loanable funds" market), that for domestic money and that for foreign exchange. The asset market locates a rate of return at which investment demand is equated with total (including net foreign) saving supply. Investment demand is non-linear, depending on a ratio similar to Tobin's $Q$ in which the numerator depends on the net rate of return on installed capital while the denominator depends on the market interest rate. Investment therefore depends positively on the quantity of effective labour employed and negatively on the market interest rate. ${ }^{35}$ This relationship takes the form

$$
I=K\left[\gamma \frac{\left(1+M P_{K}-\delta\right)}{(1+r)^{\varepsilon}}-1\right]
$$

Where $K$ is the total stock of physical capital, which is unchanged in the length of run under consideration. $M P_{K}$ is the marginal product of physical capital, which varies as the level of employment changes. $\delta$ is the depreciation rate, $r$ is the real interest rate and $\varepsilon$ is a positive elasticity.

Saving has three components: $S_{T}=S+S_{G}+S_{N F}$. Private saving by Chinese residents is $S=Y-T-C$, where taxation, at a constant marginal rate, $\tau$, is: $T=t+\tau Y$. Consumption takes the usual reduced form: 


$$
C=a_{C}-b_{C} r+c_{C}(Y-T) .
$$

Where the second term represents mainly wealth effects on consumption and $c_{C}$ is the marginal propensity to consume. Public saving is $S_{G}=T-G$, where government spending, $G$, is exogenous. And that part of public saving that is committed to the domestic economy is $S_{G D}=S_{G}-\Delta R=T-G-\Delta R$, where $\Delta R$ is the annual increment to official foreign reserves. Finally, the net inflow of private saving through the capital account of the balance of payments needs to be added. It depends on the interest premium paid to domestic investors, $r-r^{*}$, where the foreign interest rate, $r^{*}$, is exogenous:

$$
S_{N F}=a_{F S}+b_{F S}\left(r-r^{*}\right) .
$$

To clear the loanable funds market, then, we have that

$$
I=S+S_{G D}+S_{N F}=Y-C-G-\Delta R+S_{N F} .
$$

This is the Hicksian $I S$ condition for the open economy.

The next of the three markets is that for domestic currency. Here we use a straightforward real money demand curve, $m_{D}=a_{M}+b_{M} Y-c_{M} r$ and define real money supply in terms of the nominal money supply, $M_{S}$, and the GDP deflator, $P^{Y}$. Together, these yield the Hicksian $L M$ curve:

$$
m_{D}=a_{M D}+b_{M D} Y-c_{M D} r=m_{S}=\frac{M_{S}}{P^{Y}}
$$

And the nominal money supply is linked to the monetary base via the conventional money multiplier:

$$
\frac{M_{S}}{M_{B}}=\frac{1+c}{\rho+c}
$$

Where $c$ is here the cash to deposit ratio and $\rho$ is the reserve to deposit ratio.

The final demand side market is that for foreign exchange. For this we need to characterise the balance of payments. Net inflows on the capital account are $K A=S_{N F}-\Delta R$ and, ignoring "invisibles", net inflows in the current account are $C A=X-M$. The balance of payments requires that $K A+C A=O$ and so

\footnotetext{
${ }^{35}$ Current empirical testing of this formulation against investment data for other countries suggests its performance is better than Q and considerably better than formulations that include the interest rate alone. Details of this testing are available directly from the authors.
} 


$$
S_{N F}-\Delta R=M-X
$$

Where exports and imports depend on the rate at which bundles of home goods can be exchanged for corresponding bundles of foreign goods, or the real exchange rate, and on home disposable income:

$$
\begin{aligned}
& M=a_{M}+b_{M} e_{R}+c_{M}(Y-T) \\
& X=a_{X}-b_{X} e_{R}
\end{aligned}
$$

Where $e_{R}$ is the real exchange rate, defined as the number of foreign bundles that can be exchanged for an equivalent home bundle. It can be expressed in terms of the nominal exchange rate as:

$$
e_{R}=E \frac{P^{Y}}{P^{*}}
$$

Where the nominal exchange rate is foreign currency per unit of domestic currency. Note that the Hicksian IS condition for the open economy (equation 4) and the balance of payments (equation 7) collectively imply the standard aggregate expenditure identity, $Y=C+I+G+X-M$.

The supply side:

Real GDP is a Cobb-Douglas function of effective labour use, $\theta L$, skill use, $S_{K}$, and physical capital use, $K$. Only effective labour use is variable in the length of run considered here and only employment, $L$, is endogenous.

$$
Y=\alpha(\theta L)^{\beta_{L}} S_{K}^{\beta_{S}} K^{\beta_{K}}, \quad \beta_{L}+\beta_{S}+\beta_{K}=1 .
$$

From equation (11), the marginal product of physical capital is

$$
M P_{K}=\frac{\beta_{K} Y}{K}=\left[\alpha \beta_{K} S_{K}^{\beta_{S}} K^{\beta_{K}-1}\right](\theta L)^{\beta_{L}} .
$$

Where the term in square parentheses is constant in our applications. Firms profit maximisation sets this equal to the production real wage:

$$
w=\frac{W}{P^{Y}}=M P_{K} .
$$

And, finally, the rate of unemployment of ordinary (production) workers is

$$
u=\frac{F-S_{K}-L}{F} .
$$


Where $F$ is the number of both skilled and unskilled workers in the labour force.

Reference values for all endogenous variables are representative of the Chinese national accounts for 1996 and are reported in Table 2. The parameter values used are reported in Table 3 .

\section{The Effects of Internal and External Shocks}

We apply to model to the estimation of the Chinese economy's response to two external and two domestic shocks under fixed and floating exchange rates, for different degrees of capital mobility. The degree of capital mobility can be varied by adjusting the parameter $b_{F S}$, the elasticity of net foreign savings $\left(S_{N F}\right)$ to the interest differential $r-r^{*}$. The base value of $b_{F S}=4.6$ (Table 3 ) was calibrated from the observed change in private flows on the capital account in the two years 1996-98 and the corresponding change in the Chinese interest premium. ${ }^{36}$ We assign twice this value to represent 'high' capital mobility.

The four shocks considered are: (i) an increase in the foreign interest rate $r^{*}$; (ii) a fall in the foreign price level $P^{*}$; (iii) a fall in $c_{C}$, the marginal propensity to consume; and (iv) a rise in $\theta$, representing a labour-saving technical change. The first two shocks are representative of the consequences for China of the Asian crisis, which, as noted above, involved a rise in the risk premium on investment and a real appreciation relative to most trading partners. The third represents a shift in household behaviour toward private saving, presumably driven by domestic structural reform. The increase in $\theta$ is a different shock altogether but nonetheless an important one for an economy as rapidly growing as China. The associated rise in labour productivity might be the result of domestic innovation or a spillover effect from continued foreign direct investment in China.

The rise in $r^{*}$ is intended to capture the increase in the premium demanded on investments in China, observed to be 250 basis points (a $40 \%$ increase on the reference level). Following Tyers and Yang (2000), the fall in $P^{*}$ is set at 3.5\%. To obtain an estimate for the fall in the marginal propensity to consume, $c_{C}$, the model is initially subjected to the 1996-98 Asian crisis shocks together, in a calibration exercise. For this 
purpose the Asian crisis shocks also include ( $i$ ) the observed fiscal expansion, of about a per cent of GDP over the two years, and (ii) the reduction in the rate at which foreign reserves were being accumulated, from about US\$30 billion per year through 1997 to US $\$ 5$ billion in 1998. So the primary shocks in this exercise are to $r^{*}, P^{*}, G$, and $\Delta R$. To complete the calibration, however, instead of holding $c_{C}$ exogenous as a behavioural parameter and solving for, among other things, an endogenous level of domestic investment, $I$, we make $I$ exogenous, impose the observed change in $\mathrm{it}^{37}$, and make $c_{C}$ endogenous. ${ }^{38}$ The results from this calibration experiment appear in Table 4. The estimated fall in $c_{C}$ is $10 \%$, implying a $40 \%$ rise in the marginal propensity to save. The technical change shock is more speculative. For the sake of this analysis a notional $4 \%$ change in $\theta$ is chosen.

The next step is to subject the model to each of the shocks (to $r^{*}, P^{*}, c_{C}$, and $\theta$ ) individually. This is done four times in each case, where the four solutions represent $(i)$ a fixed nominal exchange rate with "base" and "high" capital mobility, and (ii) a floating nominal exchange rate with base and high capital mobility. The two exchange rate regimes represent standard closures When the exchange rate floats, it is assumed that the authorities target the price level (the GDP deflator, $P^{Y}$ ), keeping it constant. When it is fixed, monetary policy is assumed to be enslaved to the exchange rate target and hence endogenous. The change in official foreign reserves, however, remains exogenous so that the composition of any change in the central bank's assets can be varied exogenously. ${ }^{39}$ In fact, we leave the rate of accumulation of official foreign reserves unaltered at its pre-crisis level of US\$ 30 billion per year in all our experiments. ${ }^{40}$

\footnotetext{
36 Fernald and Babson (1999) estimate the premium to have risen from about 125 to 375 basis points during this period. At the same time, from Tyers and Yang (2000) estimate that private flows on the capital account transited from a net inflow of US\$30 billion to a net outflow of US\$25 billion.

${ }^{37}$ Although total investment did rise slightly in the period 1996-98, all of the increase was in loss-making state-owned enterprises, while private investment fell. Since this dichotomy is not represented in the model, we adopt for our stylised model an investment change of zero.

${ }^{38}$ We use the GEMPACK software to solve the model, which is simply a system of $m$ non-linear simultaneous equations in $n$ unknowns. $n-m$ variables are specified as exogenous so that the $m$ equations can be solved for the remaining $m$ endogenous variables. There is, however, considerable flexibility about the particular variables that are chosen to be made exogenous and endogenous. Here we make a simple switch.

${ }^{39}$ In this comparative static model we compare two equilibria and so cannot track the precise annual change in the central bank's assets. We know, however, that the change in the monetary base, $M_{B}$, is the sum of the corresponding changes in domestic credit (holdings of domestic government bonds), $D C$, and
} 
In each closure the supply side variables $F, K$ and $S_{K}$ are exogenous, as are the consumption parameters, including the marginal propensity to consume, $c_{C}$, the tax parameters $t$ and $\tau$, government spending, $G$, (as indicated above) the change in reserves, $\Delta R$, and the money multiplier parameters, $\rho$ and $c$. Also, in all six solutions, it is assumed the nominal wage, $W$, is fixed over the length of run considered. ${ }^{41}$ The remaining variables are either differently classified in the fixed and flexible exchange rate closures or, where they remain exogenous, they are subjected to shocks.

\section{Closure 1: Fixed exchange rate}

Exogenous: $E, P^{*}, r^{*}, \theta, c_{C}$

Endogenous: $P^{Y}, Y, I, u, M_{S}, M_{B}, X, M, e_{R}$

\section{Closure 2: Flexible exchange rates}

Exogenous: $P^{Y}, P^{*}, r^{*}, \theta, c_{C}$

Endogenous: $Y, I, u, M_{S}, M_{B}, X, M, E, e_{R}$

Shocks (for low, reference and high capital mobility: $b_{F S}=2.3,4.6,9.2$ ):

Change in $r^{*}:+40 \%$

Change in $P^{*}:-3.5 \%$

Change in $c_{C}:-9.5 \%$

Change in $\theta:+4 \%$

As indicated earlier, each shock is imposed four times (two for each exchange rate regime), resulting in a total of 16 simulations.

foreign reserves (holdings of foreign bonds), $R$. Or that $\Delta M_{B}=\Delta D C+\Delta R$. Any endogenous change in $M_{B}$, combined with an exogenous change in $R$ therefore implies a particular pattern of sterilisation through $\Delta D C$, which is assumed to be achieved through domestic open market operations.

${ }^{40}$ It might be argued that salting away $3 \%$ of GDP overseas each year represented particularly conservative behaviour by the government and that this acted to suppress the equilibrium exchange rate. This issue is taken up by Bu and Tyers (2000).

${ }^{41}$ Even though China's labour markets are highly regulated by the standards of most developing countries, this is a strong assumption that one would expect to lead to some overestimation of real effects. 


\section{Experiment 1: Rise in $r^{*}$}

When the nominal exchange rate is fixed, the rise in $r^{*}$ stimulates a private outflow on the capital account. To keep the nominal exchange rate from appreciating, the authorities must lower the money supply, raising the interest rate. The associated financial contraction results in an excess of aggregate supply over demand and a lower price level. When the nominal wage is rigid this raises the real wage, reducing GDP and income. The increased private outflow on the capital account causes a depreciation of the real exchange rate. Exports rise and imports fall. These changes are clear from the numerical results in Table 5.

As capital mobility increases the effect of this external shock magnifies the change in private flows on the capital account (the proportional contraction in net private inflow, $S_{N F}$, is larger by half with the transition to high mobility), increasing the required adjustment in other variables. The deflation that results under the fixed exchange rate regime is larger the greater is capital mobility, the percentage decline almost doubling in the transition to the "high mobility" cases. Accordingly, the real depreciation is enlarged with greater mobility and so the trade balance improves more substantially the more mobile is capital. This only partially offsets the effects of the deflation on output and employment, however. The output contraction also almost doubles with the transition to high capital mobility.

Were the exchange rate sufficiently flexible to allow independent monetary policy, however, it would be possible to avoid the real wage changes that harm employment and output by targeting the price level. In this case, much of the adjustment is borne by variations in the nominal and real exchange rates, which also enlarge by half with the transition to high capital mobility. Constant aggregate income means that consumption is somewhat insulated from the shock, despite a slightly larger increase in the domestic rate of return $r$, for all capital mobility settings. The trade balance improves by slightly less than it would with a fixed exchange rate, for all capital mobility settings, because despite a greater fall in the real exchange rate (boosting exports and contracting imports), constant income ensures that the effect on imports is smaller. 


\section{Experiment 2: Fall in $P^{*}$}

Were the exchange rate floating, the fall in $P^{*}$ would have no real effects in our simple model. It would simply cause an offsetting nominal depreciation, leaving the domestic price level unchanged. ${ }^{42}$ In the fixed exchange rate world the central bank resists this tendency to depreciate with monetary tightening. This reduces the home price level, which has two consequences. First, it ensures that, by definition (equation 10) there is a real appreciation. Second, it is contractionary, raising the home real wage and lowering output and employment. The real contraction lowers private saving, which would normally cause the domestic interest rate to rise, but it also lowers the real return on installed capital. In this particular case the latter effect shifts investment demand sufficiently to cause the home rate of return to fall slightly. ${ }^{43}$ This causes a slight diminution of private net inflows on the capital account. On the current account this is balanced by a shift toward surplus. Here, again, there are two offseting effects. By itself, the real appreciation tends to cause a deterioration in the current account, but in this case the dominant effect is a reduction in imports due to the real income contraction. As indicated in Table 6, because the changes in flows on the balance of payments are comparatively small in this case, the preceding causal sequence is comparatively insensitive to the level of capital mobility.

\section{Experiment 3: Autonomous savings increase (fall in $c_{C}$ )}

An autonomous fall in the marginal propensity to consume increases total saving and reduces the equilibrium rate of return in the market for "bonds", as indicated in Table 7. Alternatively, it reduces aggregate demand relative to supply, lowering both the domestic interest rate, the price level. The deflation raises the real wage, which reduces employment and aggregate output. The fall in $r$ - $r^{*}$ sparks a substantial capital outflow. Under a fixed exchange rate policy the central bank contracts the money supply to prevent a nominal depreciation, but the net effect on $r$ remains negative. As capital

\footnotetext{
${ }^{42}$ This result depends on the assumption that the GDP deflator always indicates the domestic price level. Since this remains unchanged there is no change in the real production wage and hence no real effects. If, however, the labour market rigidity took the form of rigid real take-home pay, the consumer price index would become important.

${ }^{43}$ In this comparative static model, the home rate of return is the equivalent of the long term borrowing rate. The monetary contraction would be expected to raise the short term rate.
} 
mobility rises, the outflow on the capital account increases and the total supply of savings to finance domestic investment decreases. The fall in the domestic rate of return is mitigated, magnifying the negative effect on consumption. Consequently the effects on income, employment and the price level become increasingly negative as capital becomes more mobile. Of course the corollary to the shift in the capital account toward deficit is a shift toward surplus in the current account, by a magnitude that enlarges with capital mobility.

Since a flexible exchange rate makes it possible for the authorities to stabilise the price level, it completely insulates income and employment from the effects of this shock. Expansionary monetary policy lowers $r$ even further, expanding investment demand, while the nominal depreciation allows net exports to expand by a greater amount than they do in the fixed exchange rate case. Together, these two effects completely offset the effect of the fall in consumption, for all three levels of capital mobility.

\section{Experiment 4: Labour-saving technical change (rise in $\theta$ )}

A rise in the productivity of labour increases aggregate supply relative to demand, which increases output and lowers the price level when the nominal wage is fixed. The lower price level expands the real money supply, which would otherwise tend to reduce the interest rate, but in this case a higher $\theta$ increases the marginal product of installed capital and boosts investment demand, ensuring that the net effect on the domestic rate of return is positive. This, in turn, raises net inflows on the capital account. As indicated in Table 8, when the nominal exchange rate is fixed, this requires an easing of monetary policy to prevent a nominal appreciation. Still the net effect on the domestic rate of return remains positive.

The net fall in the price level lowers the real exchange rate, but rising income boosts imports sufficiently to worsen the trade balance. As capital mobility rises, net exports tend to fall, since the changes in exports and imports rise and fall respectively. Overall, the effect of increased capital mobility is less unattractive in this scenario. Indeed, investment, consumption and employment all improve slightly as capital mobility increases. 
Were the nominal exchange rate flexible, however, the improvement in income and employment more than doubles, since the focus of monetary policy on the price level ensures that the real wage does not rise. The real exchange rate falls by a greater amount than it does under a fixed exchange rate, and the trade balance worsens progressively the greater is capital mobility, but the net effect on exports remains positive.

\section{Extensions}

The model simulated in the previous section helps consolidate some key intuitions about Chinese exchange rate policy; specifically the 'insulation' property of flexible exchange rates, and the idea that increased capital mobility should magnify the volatility in prices and income caused by a peg to the dollar. The model has clear drawbacks, however. In particular, since its comparative static structure ignores the dynamic and expectational aspects of the economy, such as: $(a)$, the effect of price level changes on inflation expectations and hence on the real interest rate, and $(b)$, potential 'overshooting' effects that might, by increasing exchange rate volatility, make a flexible regime less attractive. Finally, the assumption of nominal wage rigidity is extreme, even for China's regulated economy, as wages in China's dynamic private sector are more flexible than in the highly regulated state sector.

A more complete analysis would specify a dynamic general equilibrium model of the Chinese economy, in which the stance of exchange rate policy and the degree of capital mobility could be embedded. Although models of this sort are unknown in the Chinese economy literature, recent developments in international macroeconomics suggest they may constitute a fruitful topic for future research. In particular, the 'New Open Economy Macroeconomic Models' developed by Obstfeld and Rogoff (1995b, 1998, 2000) and Devereux and Engel (1998) show much promise as a means of capturing the intuitions of traditional Mundell-Fleming-Dornbusch approaches in microfounded sticky-price or sticky-wage DGE models. ${ }^{44}$ A key advantage of these models is that, by describing the behaviour of representative agents through explicit utility and profit maximisation problems, they make formal welfare analysis possible. A weakness of the comparative-static approach used in the previous section is that it is only relevant for

\footnotetext{
${ }^{44}$ See Lane (1999) for a survey.
} 
short-run analysis. By applying the intertemporal approach to the Chinese economy, much could be learnt about the long-run effects of various macroeconomic shocks under alternative currency regimes. In a stochastic context, where considerations of currency risk are appropriate, the insurance property of China's fixed exchange rate could also be meaningfully assessed. ${ }^{45}$

\section{Conclusion}

To summarise, there is a case for a more flexible exchange rate policy in China. As China's capital markets become globally integrated, a pegged exchange rate will: $(i)$ erode the independence of monetary policy, (ii), magnify variation in prices and output, and (iii) increase the risk of speculative attacks on the currency under adverse regional or domestic conditions. China's peg to the dollar is of questionable value in the post-crisis world, where regional conditions have stabilised, implying that competitive devaluation fears are no longer as severe as they were. It has been argued here that the peg may also have limited value as a nominal anchor for domestic expectations.

Experiments conducted using a simple comparative-static macroeconomic model confirm the suspicion that monetary policy could be put to good use in minimising price and output volatility when the economy is subjected to adverse external and internal shocks. When capital mobility rises, pegging the currency simply increases that volatility. This sensitivity to the level of capital mobility is strongest when the shocks are to the interest premium on Chinese investment, as during the Asian financial crisis, and to private savings behaviour, as observed in association with the domestic reform process.

While the elemental model used here supports the idea that in China's case a flexible exchange rate regime would be preferable to a pegged regime, it is not clear that a more complicated model, augmented to incorporate dynamics and expectational effects, would produce the same result. In particular, the insurance effect of a fixed exchange rate is not adequately addressed in the framework employed here. A more flexible regime could prove harmful to trade and direct investment flows. While the case for a

\footnotetext{
${ }^{45}$ See Engel (1999) for a discussion of the foreign exchange risk premium in these models. The caveat, of course, is that until China develops a forward exchange rate the insights of this literature, which assumes that agents can hedge against currency risk, will have to be modified.
} 
flexible renminbi should be qualified by these considerations, it is clear that it must be taken seriously by policymakers as they continue to plan China's economic transition.

\section{References}

Benassy-Quere, A. (1996), "Exchange rate regimes and policies in Asia", CEPII Working Paper No. 96-09.

Bu, Y. and R. Tyers (2001), “China's Equilibrium Real Effective Exchange Rate: An Aggregated General EquilibriumApproach", Working Papers in Economics and Econometrics No. 390, Australian National University (http://ecocomm.anu.edu.au/departments/economics/staff/tyers.html).

Chen, X.B. (1999) "An analysis of the real exchange rate of the RMB", The Economic Research Journal, 1:22-28 (in Chinese).

Cottarelli, C. and C. Giannini (1997) "Credibility without rules? Monetary frameworks in the post-Bretton Woods era", IMF Occasional Paper 154, Washington DC.

Corden, W.M. (1993) "Exchange rate policies for developing countries", Economic Journal, 103: 198-207.

Edwards, S. and M.A. Savastano (1999) "Exchange rates in emerging economies: what do we know? What do we need to know?", NBER Working Paper 7228.

Engel, C. (1999) "On the foreign exchange risk premium in sticky-price general equilibrium models", NBER Working Paper 7067.

Devereux, M. and C. Engel (1998) "Fixed vs. floating exchange rates: how price setting affects the optimal choice of exchange-rate regime", NBER Working Paper No. 6867.

Dornbusch, R. (1999) “Don't devalue the Renminbi”, The $5^{\text {th }}$ Column, Far Eastern Economic Review, August 26, p.30.

Fernald, J.G and O.D. Babson (2000) "Why has China survived the financial crisis so well: what risks remain?", in Chen et al., Financial Market Reform in China: Progress, Problems and Prospects, Boulder: Westview Press.

Frankel, J.A. (2000) "No single currency regime is right for all countries or at all times", NBER Working Paper No. 7338.

Friedman, M. (1953) "The case for flexible exchange rates", in Essays in Positive Economics, Chicago: University of Chicago Press.

Fung, K. et al. (2000) "The impact of credit control and interest rate regulation on the transforming Chinese economy: an analysis of long-run effects", Journal of Comparative Economics, 28: 293-320.

Huang, F. (1999) "The current economic situation and trends in China - with a discussion on employment-related issues in the process of industrialization", Journal of Asian Economics, 10: 279-289.

Huang, G. and Y. Li (1996) "Capital flow, sterilisation and the independence of monetary policy: the case of China", in Tisdell, C.A. and J.C.H. Chai (eds.) China's Economic Growth and Transition, Proceedings of the International Conference on China and the Asia-Pacific (July 1996), Department of Economics, University of Queensland, Brisbane. 
IMF (2000a) World Economic Outlook, May 2000, Washington, DC.

IMF (2000b) World Economic Outlook, October 2000, Washington, DC.

IMF (2001a) World Economic Outlook, May 2001, Washington, DC.

IMF (2001b) "IMF concludes 2001 Article IV consultation with the People's Republic of China", Public Information Notice No. 01/91 (24 August, 2001), Washington, DC.

Ishiyama, Yoshide (1975) "The theory of optimum currency areas: a survey", IMF Staff Papers, 22: 344-383.

Kenen, P.B. (1969) "The theory of optimum currency areas: an eclectic view", in Mundell, R.A. and A.K Swoboda (eds.) Monetary Problems of the International Economy, Chicago: University of Chicago Press.

Lane, P.R. (1999) “The new open economy macroeconomics: a survey”, CEPR Discussion Paper No. 2115.

Little, I.M.D. et al. (1993) Boom, Crisis and Adjustment: The Macroeconomic Experience of Developing Countries, New York: Oxford University Press.

Mathieson, D.J. and L. Rojas-Suarez (1993) "Liberalization of the capital account: experiences and issues", IMF Occasional Paper 103.

McKinnon, R.I (1963) "Optimum currency areas", American Economic Review, 53 : 717-725.

Mehran, H. et al. (1996) "Monetary and exchange system reform in China: an experiment in gradualism", IMF Occasional Paper 141.

Mishkin, F. (1999) "International experiences with different monetary policy regimes", Journal of Monetary Economics, 43: 579-605.

Mundell, R.A. (1961) "A theory of optimum currency areas", American Economic Review, 51: 657-665.

$\mathrm{Ni}, \mathrm{W}$. (1999) "An analysis of the effect of currency depreciation in a non-equilibrium environment", Economic Research, No.4 (in Chinese).

Oppers, S.E. (1997) "Macroeconomic cycles in China”, IMF Working Paper No. 135.

Obstfeld, M. and K. Rogoff (1995a) "The mirage of fixed exchange rates", Journal of Economic Perspectives, 9: 73-96.

Obstfeld, M. and Rogoff, K. (1995b), "Exchange rate dynamics redux", Journal of Political Economy, 103: 624-660.

Obstfeld, M. and Rogoff, K. (1998), "Risk and exchange rates", NBER Working Paper No. 6694

Obstfeld, M. and Rogoff, K. (2000), "New directions for stochastic open economy models", Journal of International Economics, 50: 117-153.

Song, L. (1998), "China", in McLeod, R.H and R. Garnaut (eds.) East Asia in Crisis: From Being a Miracle to Needing One, London: Routledge.

Tyers, R. (2000), "China after the crisis: the elemental macroeconomics", Asian Economic Journal, 15(2): 173-199, August 2001.

Tyers, R. and Y. Yang, "Weathering the crisis: the role of China", Pacific Economic Papers No. 308, Asia-Pacific School of Economics and Management, Australian National University, November 2000 (http://ecocomm.anu.edu.au/departments/economics/staff/tyers.html). 
World Bank (1999) Global Development Finance, Washington, DC.

Yi, Gang (1994) Money, Banking and Financial Markets in China, Boulder: Westview Press.

Zhang, M. and G. Shen (2000) "The relationship between export expansion and the renminbi exchange rate mechanism: an investigation" [in Chinese], in The Study of Finance and Economics [Caijing Yanjiu], Vol.26, No.1.

Zhang, Z. (1999) "Exchange rate reform in China: an experiment in the real targets approach", St Anthony's College, Oxford University. 
Figure 1

PRC Export Market: Percentage Shares

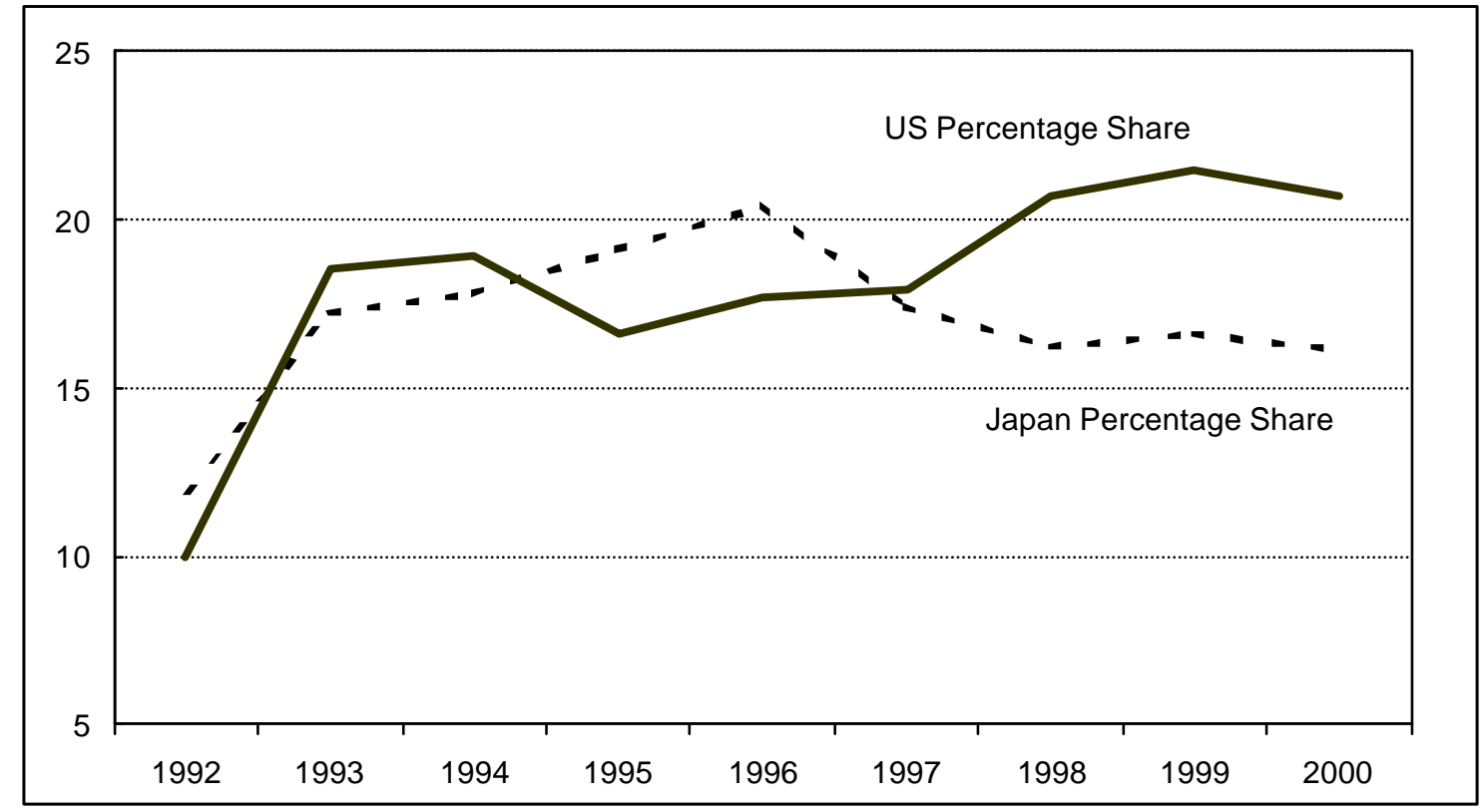

Source: Data are from Datastream (drawn originally from the China Statistical Information Service Centre).

Figure 2

PRC Import Supply - Percentage Shares

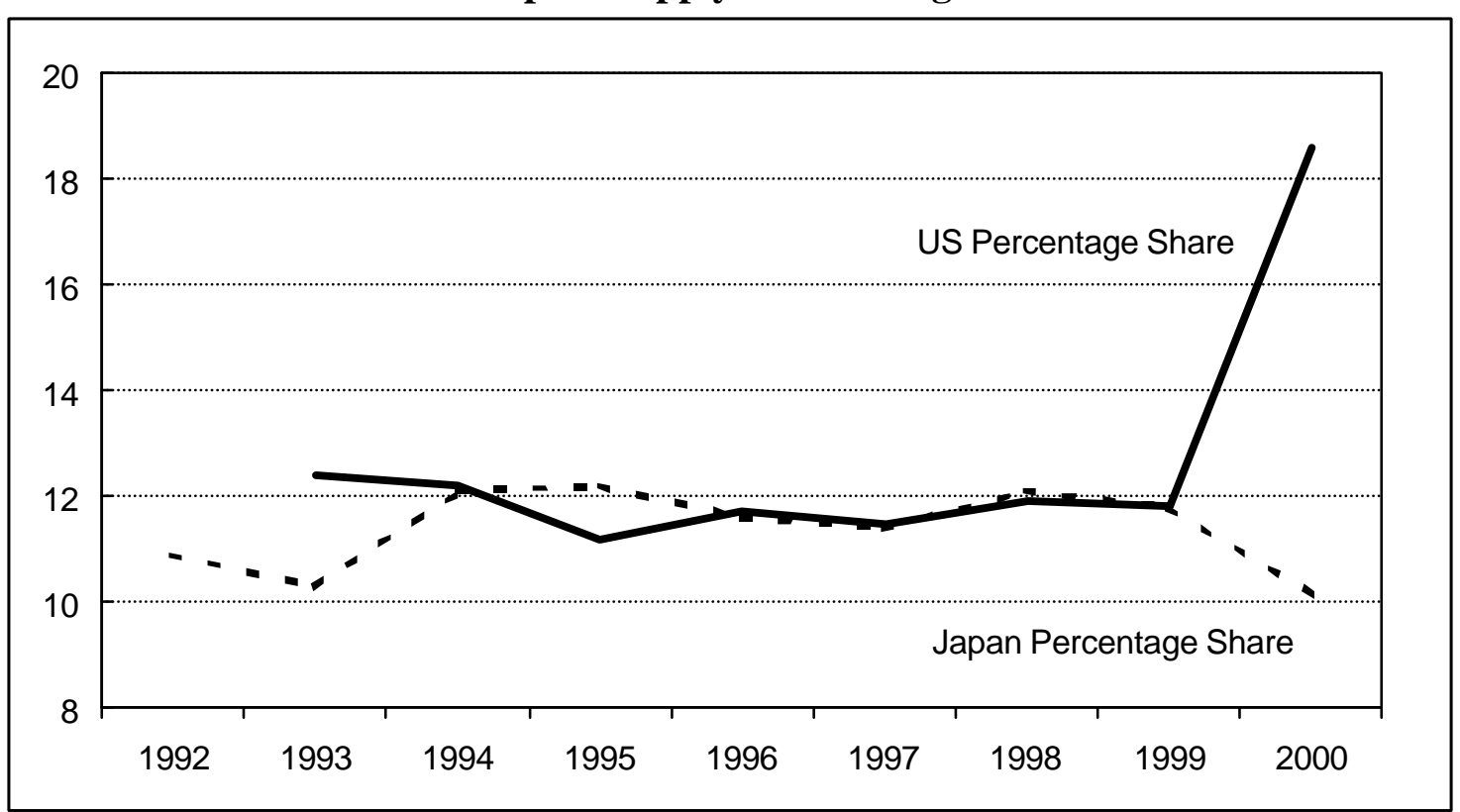

Source: Data are from Datastream (drawn originally from the China Statistical Information Service Centre). 
Table 1: Economic Indicators, 1992-2000

\begin{tabular}{|c|c|c|c|c|c|c|}
\hline Year & $\begin{array}{r}\text { Capital } \\
\text { flight } \\
\text { US\$ bn }\end{array}$ & $\begin{array}{l}\text { CPI growth } \\
\% \text { per year }\end{array}$ & $\begin{array}{r}\text { Real GDP } \\
\text { growth } \\
\% \text { per year }\end{array}$ & $\begin{array}{r}\text { FDI } \\
\text { US\$ bn }\end{array}$ & $\begin{array}{r}\text { Export } \\
\text { growth } \\
\% \text { per year }\end{array}$ & $\begin{array}{r}\text { Government } \\
\text { spending } \\
\text { Bn Yuan }\end{array}$ \\
\hline 1992 & -56.8 & 6.4 & 14.2 & 11.2 & 18.32 & 374 \\
\hline 1993 & -19.9 & 14.7 & 13.5 & 27.5 & 7.95 & 464 \\
\hline 1994 & -20.4 & 24.1 & 12.6 & 33.8 & 31.88 & 579 \\
\hline 1995 & -32.3 & 17.1 & 10.5 & 35.8 & 22.95 & 682 \\
\hline 1996 & -30.5 & 8.3 & 9.6 & 40.2 & 1.53 & 794 \\
\hline 1997 & -63.5 & 2.8 & 8.8 & 44.2 & 21.01 & 923 \\
\hline 1998 & -63.2 & -0.8 & 7.8 & 43.8 & 0.56 & 1080 \\
\hline 1999 & -43.0 & -1.3 & 7.2 & 38.8 & 6.05 & 1314 \\
\hline 2000 & -50.2 & 0.3 & 7.8 & - & 27.85 & - \\
\hline
\end{tabular}

Source: Capital flight data (net US\$bn) are estimates from The Economist Intelligence Unit (acquired from Datastream). CPI growth, FDI (US\$bn), export growth and government spending (billion yuan) are all from IMF International Financial Statistics.

Table 2: Reference values of key model variables:

\begin{tabular}{lrlr}
\hline Variable & $\begin{array}{r}\text { Base } \\
\text { value, } \\
\text { US\$ bn }\end{array}$ & Variable & $\begin{array}{r}\text { Base } \\
\text { value }\end{array}$ \\
\hline GDP, $Y$ & 1000 & Real interest rate, $r$ & $7.00 \%$ \\
Consumption, $C$ & 500 & Foreign int. rate, $r^{*}$ & $6.25 \%$ \\
Investment, $I$ & 370 & Domestic prices, $P$ & 1.0 \\
Govt. spending, $G$ & 130 Foreign prices, $P^{*}$ & 1.0 \\
Exports, $X$ & 160 Nom. Ex. Rate, $E$ & 1.0 \\
Imports, $M$ & 160 & Real ex. Rate, $e_{R}$ & 1.0 \\
Tax, $T$ & 120 & & \\
Money supply, $M_{S}$ & 470 & & \\
Monetary base, $M_{B}$ & 135 & & \\
Capital stock, $K$ & 2000 & & \\
Skill, $S_{K}$ & 100 & & \\
Labour use, $L$ & 375 & & \\
Labour force, $F$ & 500 & & \\
Net for. saving, $S_{N F}$ & 30 & & \\
Reserve Accum., $\Delta R$ & 30 & & \\
\hline Source: & & \\
\hline
\end{tabular}

Source: Indicative values structured to resemble national accounts data for 1996. See Tyers (2000). 
Table 3: Reference Values of Key Parameters

\begin{tabular}{lr}
\hline Parameter & Value \\
\hline Shares of value added: & 0.45 \\
$\quad$ variable labour, $\beta_{L}$ & 0.20 \\
$\quad$ skill, $\beta_{S}$ & 0.35 \\
physical capital, $\beta_{K}$ & \\
Elasticity of real money demand to: & 0.5 \\
$\quad$ income, $Y$ & 0.1 \\
$\quad$ interest rate, $r$ & 0.2 \\
Marginal tax rate $\tau$ & 0.8 \\
Marginal propensity to consume, $c_{C}$ & 0.1 \\
Response of consumption to the interest rate, $r$ & 3.5 \\
Money multiplier, $M_{S} / M_{b}$ & 2.0 \\
Elasticity of imports, $M$, to the real exchange rate, $e_{R}$ & 0.3 \\
Marginal propensity to import, $c_{M}$ & 1.5 \\
Elasticity of exports, $X$, to the real exchange rate, $e_{R}$ & 4.6 \\
Elasticity of net foreign saving, $S_{N F}$, to the interest rate, $r$ & -3.0 \\
Elasticity of proportional investment, $(K+I) / K$ to $(l+r),-\varepsilon$ & \\
\hline Source: Indicative estimates only, drawn from other country studies. See Tyers $(2000)$. &
\end{tabular}

Source: Indicative estimates only, drawn from other country studies. See Tyers (2000). 
Table 4: Asian Crisis Shocks: Calibrating the change in saving behaviour (All values in US\$ bn)

\begin{tabular}{|c|c|c|c|c|}
\hline Variable: & $\begin{array}{l}\text { Per cent } \\
\text { change }\end{array}$ & $\begin{array}{l}\text { Value } \\
\text { before }\end{array}$ & $\begin{array}{l}\text { Value } \\
\text { after }\end{array}$ & $\begin{array}{r}\text { Differe } \\
\text { nce }\end{array}$ \\
\hline \multicolumn{5}{|l|}{ Expenditures on GDP: } \\
\hline GDP, $Y$ & -5.4 & 1000 & 946 & -54 \\
\hline Consumption, $C$ & -18.9 & 500 & 406 & -94 \\
\hline Investment, $I$ & 0.0 & 370 & 370 & 0 \\
\hline Government spending, $G$ & 7.7 & 130 & 140 & 10 \\
\hline Exports, $X$ & 4.7 & 160 & 168 & 8 \\
\hline Imports, $M$ & -14.4 & 160 & 137 & -23 \\
\hline \multicolumn{5}{|l|}{ Balance of payments: } \\
\hline Private net inflow, $S_{N F}$ & -185 & 30 & -25 & -55 \\
\hline Change in official reserves, $\Delta R$ & -83 & 30 & 5 & -25 \\
\hline Current account surplus, $X-M$ & & 0 & 31 & 31 \\
\hline \multicolumn{5}{|l|}{ Saving: } \\
\hline Marginal propensity to consume, $c_{C}$ & -9.6 & 0.80 & 0.72 & -0.08 \\
\hline Disposable income, $Y_{D}$ & -9.0 & 120 & 109 & -11 \\
\hline Tax revenue, $T$ & 207.8 & -10 & -31 & -21 \\
\hline Government saving, $T-G$ & -10.3 & -40 & -36 & 4 \\
\hline Govt saving at home, $T-G-\Delta R$ & 13.5 & 380 & 431 & 51 \\
\hline \multicolumn{5}{|l|}{ Domestic private saving, $S$} \\
\hline Nominal money supply: & -8.6 & 135 & 123 & -12 \\
\hline Monetary base, $B$ & -8.6 & 470 & 429 & -41 \\
\hline \multicolumn{5}{|l|}{ Nominal money supply, $M_{S}$} \\
\hline \multicolumn{5}{|l|}{ Interest rate: } \\
\hline Return on installed capital, $M P_{K^{-}} \delta$ & -12.6 & 0.07 & 0.07 & -0.01 \\
\hline Home interest rate, $r$ & -4.5 & 0.07 & 0.07 & 0.00 \\
\hline Foreign interest rate, $r^{*}$ & 40.0 & 0.06 & 0.09 & 0.02 \\
\hline \multicolumn{5}{|l|}{ Exchange rate: } \\
\hline Real exchange rate, $e_{R}$ & 0.0 & 1.0 & 1.0 & 0.0 \\
\hline Nominal exchange rate, $E$ & -3.2 & 1.0 & 1.0 & 0.0 \\
\hline \multicolumn{5}{|l|}{ Supply side: } \\
\hline Real wage, $w=W / P$ & 7.0 & 1.20 & 1.28 & 0.08 \\
\hline Nominal wage, $W$ & 0.0 & 1.20 & 1.20 & 0.00 \\
\hline Tech factor, $\theta$ & 0.0 & 1.00 & 1.00 & 0.00 \\
\hline Employment, $L$ & -11.6 & 375 & 332 & -43 \\
\hline Unemployment rate, $u$ & 173 & 0.05 & 0.14 & 0.09 \\
\hline \multicolumn{5}{|l|}{ Price level: } \\
\hline Home price level, $P$ & -6.5 & 1.00 & 0.93 & -0.07 \\
\hline Foreign price level, $P^{*}$ & -3.5 & 1.00 & 0.96 & -0.04 \\
\hline
\end{tabular}

a The exogenous shocks are to the foreign price level, $P^{*}$, the foreign interest rate, $r^{*}$, government spending, $G$, and the change in foreign reserves, $\Delta R$. The nominal exchange rate, $E$, is held fixed to reflect the fixed exchange rate policy. The nominal wage, $W$, is held fixed to represent labour market rigidity and domestic investment, $I$, is held constant by observation (this is the variable that is swapped from endogenous to exogenous in order to calibrate the change in the marginal propensity to consume). Source: Simulations using the model discussed in the text. 


\section{Table 5: Simulated effects of a rise in the foreign interest rate, $r^{*}$}

(Per cent change unless otherwise indicated)

\begin{tabular}{|c|c|c|c|c|}
\hline \multirow[b]{2}{*}{ Variable: } & \multicolumn{2}{|c|}{ Fixed exchange rate } & \multicolumn{2}{|c|}{$\begin{array}{r}\text { Flexible exchange } \\
\text { rate }\end{array}$} \\
\hline & $\begin{array}{r}\text { Base } \\
\text { capital } \\
\text { mobility }\end{array}$ & $\begin{array}{r}\text { High } \\
\text { capital } \\
\text { mobility }\end{array}$ & $\begin{array}{r}\text { Base } \\
\text { capital } \\
\text { mobility }\end{array}$ & $\begin{array}{r}\text { High } \\
\text { capital } \\
\text { mobility }\end{array}$ \\
\hline \multicolumn{5}{|l|}{ Expenditures on GDP: } \\
\hline GDP, $Y$ & -4.3 & -7.2 & 0.0 & 0.0 \\
\hline Consumption, $C$ & -7.1 & -11.9 & -1.4 & -2.4 \\
\hline Investment, $I$ & -13.0 & -21.7 & -8.8 & -14.6 \\
\hline Government spending, $G$ & 0.0 & 0.0 & 0.0 & 0.0 \\
\hline Exports, $X$ & 7.8 & 13.0 & 10.5 & 17.5 \\
\hline Imports, $M$ & -16.8 & -28.1 & -14.0 & -23.3 \\
\hline \multicolumn{5}{|l|}{ Balance of payments: } \\
\hline Private net inflow, $S_{N F}$ & -131 & -219 & -130 & -217 \\
\hline Change in official reserves, $\Delta R$ & 0.0 & 0.0 & 0.0 & 0.0 \\
\hline Current acc. surplus $^{\mathrm{a}}, \Delta(X-M)$, US $\$$ bn & 39.4 & 65.7 & 39.2 & 65.3 \\
\hline \multicolumn{5}{|l|}{ Money supply and interest rate: } \\
\hline Nominal money supply, $M_{S}$ & -7.9 & -13.0 & -0.7 & -1.2 \\
\hline Home interest rate, $r$ & 6.9 & 11.6 & 7.0 & 11.8 \\
\hline \multicolumn{5}{|l|}{ Exchange rate: } \\
\hline Real exchange rate, $e_{R}$ & -5.2 & -8.7 & -7.0 & -11.7 \\
\hline Nominal exchange rate, $E$ & 0.0 & 0.0 & -7.0 & -11.7 \\
\hline \multicolumn{5}{|l|}{ Supply side: } \\
\hline Real wage, $w=W / P$ & 5.5 & 9.5 & 0.0 & 0.0 \\
\hline Nominal wage, $W$ & 0.0 & 0.0 & 0.0 & 0.0 \\
\hline Unemployment rate, $u$ & 138 & 228 & 0.0 & 0.0 \\
\hline \multicolumn{5}{|l|}{ Price level: } \\
\hline Home price level, $P$ & -5.2 & -8.7 & 0.0 & 0.0 \\
\hline
\end{tabular}

a This is the US\$ change in the current account surplus due to the tabulated shock.

Source: Simulations using the model discussed in the text. 
Table 6: Simulated effects of a fall in the foreign price level, $P^{*}$

(Per cent change unless otherwise indicated)

\begin{tabular}{|c|c|c|c|c|}
\hline \multirow[b]{2}{*}{ Variable: } & \multicolumn{2}{|c|}{ Fixed exchange rate } & \multicolumn{2}{|c|}{$\begin{array}{r}\text { Flexible exchange } \\
\text { rate }\end{array}$} \\
\hline & $\begin{array}{r}\text { Base } \\
\text { capital } \\
\text { mobility }\end{array}$ & $\begin{array}{r}\text { High } \\
\text { capital } \\
\text { mobility }\end{array}$ & $\begin{array}{r}\text { Base } \\
\text { capital } \\
\text { mobility }\end{array}$ & $\begin{array}{r}\text { High } \\
\text { capital } \\
\text { mobility }\end{array}$ \\
\hline \multicolumn{5}{|l|}{ Expenditures on GDP: } \\
\hline GDP, $Y$ & -2.2 & -2.2 & 0.0 & 0.0 \\
\hline Consumption, $C$ & -2.9 & -2.9 & 0.0 & 0.0 \\
\hline Investment, $I$ & -2.2 & -2.2 & 0.0 & 0.0 \\
\hline Government spending, $G$ & 0.0 & 0.0 & 0.0 & 0.0 \\
\hline Exports, $X$ & -1.4 & -1.3 & 0.0 & 0.0 \\
\hline Imports, $M$ & -1.4 & -1.5 & 0.0 & 0.0 \\
\hline \multicolumn{5}{|l|}{ Balance of payments: } \\
\hline Private net inflow, $S_{N F}$ & -0.4 & -0.6 & 0.0 & 0.0 \\
\hline Change in official reserves, $\Delta R$ & 0.0 & 0.0 & 0.0 & 0.0 \\
\hline Current acc. surplus $^{\mathrm{a}}, \Delta(X-M)$, US $\$$ bn & 0.1 & 0.2 & 0.0 & 0.0 \\
\hline \multicolumn{5}{|l|}{ Money supply and interest rate: } \\
\hline Nominal money supply, $M_{S}$ & -3.7 & -3.7 & 0.0 & 0.0 \\
\hline Home interest rate, $r$ & -0.08 & -0.07 & 0.0 & 0.0 \\
\hline \multicolumn{5}{|l|}{ Exchange rate: } \\
\hline Real exchange rate, $e_{R}$ & 0.9 & 0.9 & 0.0 & 0.0 \\
\hline Nominal exchange rate, $E$ & 0.0 & 0.0 & -3.5 & -3.5 \\
\hline \multicolumn{5}{|l|}{ Supply side: } \\
\hline Real wage, $w=W / P$ & 2.7 & 2.7 & 0.0 & 0.0 \\
\hline Nominal wage, $W$ & 0.0 & 0.0 & 0.0 & 0.0 \\
\hline Unemployment rate, $u$ & 71 & 71 & 0.0 & 0.0 \\
\hline \multicolumn{5}{|l|}{ Price level: } \\
\hline Home price level, $P$ & -2.6 & -2.6 & 0.0 & 0.0 \\
\hline
\end{tabular}

a This is the US\$ change in the current account surplus due to the tabulated shock.

Source: Simulations using the model discussed in the text. 


\section{Table 7: Simulated Effects of a Fall in $c_{C}$}

(Per cent change unless otherwise indicated)

\begin{tabular}{|c|c|c|c|c|}
\hline \multirow[b]{2}{*}{ Variable: } & \multicolumn{2}{|c|}{ Fixed exchange rate } & \multicolumn{2}{|c|}{$\begin{array}{r}\text { Flexible exchange } \\
\text { rate }\end{array}$} \\
\hline & $\begin{array}{r}\text { Base } \\
\text { capital } \\
\text { mobility }\end{array}$ & $\begin{array}{r}\text { High } \\
\text { capital } \\
\text { mobility }\end{array}$ & $\begin{array}{r}\text { Base } \\
\text { capital } \\
\text { mobility }\end{array}$ & $\begin{array}{r}\text { High } \\
\text { capital } \\
\text { mobility }\end{array}$ \\
\hline \multicolumn{5}{|l|}{ Expenditures on GDP: } \\
\hline GDP, $Y$ & -1.4 & -2.4 & 0.0 & 0.0 \\
\hline Consumption, $C$ & -13.8 & -15.2 & -12.0 & -12.3 \\
\hline Investment, $I$ & 10.5 & 7.5 & 12.1 & 10.1 \\
\hline Government spending, $G$ & 0.0 & 0.0 & 0.0 & 0.0 \\
\hline Exports, $X$ & 2.6 & 4.3 & 3.5 & 5.9 \\
\hline Imports, $M$ & -5.6 & -9.3 & -4.7 & -7.8 \\
\hline \multicolumn{5}{|l|}{ Balance of payments: } \\
\hline Private net inflow, $S_{N F}$ & -43.4 & -72.3 & -43.6 & -73.1 \\
\hline Change in official reserves, $\Delta R$ & 0.0 & 0.0 & 0.0 & 0.0 \\
\hline Current acc. surplus ${ }^{\mathrm{a}}, \Delta(X-M)$, US $\$$ bn & 13.0 & 21.1 & 13.1 & 21.9 \\
\hline \multicolumn{5}{|l|}{ Money supply and interest rate: } \\
\hline Nominal money supply, $M_{S}$ & -1.5 & -3.3 & 1.0 & 0.8 \\
\hline Home interest rate, $r$ & -9.4 & -7.9 & -9.5 & -7.9 \\
\hline \multicolumn{5}{|l|}{ Exchange rate: } \\
\hline Real exchange rate, $e_{R}$ & -1.7 & -2.9 & -2.3 & -3.9 \\
\hline Nominal exchange rate, $E$ & 0.0 & 0.0 & -2.3 & -3.9 \\
\hline \multicolumn{5}{|l|}{ Supply side: } \\
\hline Real wage, $w=W / P$ & 1.8 & 3.0 & 0.0 & 0.0 \\
\hline Nominal wage, $W$ & 0.0 & 0.0 & 0.0 & 0.0 \\
\hline Unemployment rate, $u$ & 46.6 & 77.3 & 0.0 & 0.0 \\
\hline \multicolumn{5}{|l|}{ Price level: } \\
\hline Home price level, $P$ & -1.7 & -2.9 & 0.0 & 0.0 \\
\hline
\end{tabular}

a This is the US\$ change in the current account surplus due to the tabulated shock.

Source: Simulations using the model discussed in the text. 


\section{Table 8: Simulated Effects of a Rise in $\theta$}

(Per cent change unless otherwise indicated)

\begin{tabular}{|c|c|c|c|c|}
\hline \multirow[b]{2}{*}{ Variable: } & \multicolumn{2}{|c|}{ Fixed exchange rate } & \multicolumn{2}{|c|}{$\begin{array}{r}\text { Flexible exchange } \\
\text { rate }\end{array}$} \\
\hline & $\begin{array}{r}\text { Base } \\
\text { capital } \\
\text { mobility }\end{array}$ & $\begin{array}{r}\text { High } \\
\text { capital } \\
\text { mobility }\end{array}$ & $\begin{array}{r}\text { Base } \\
\text { capital } \\
\text { mobility }\end{array}$ & $\begin{array}{r}\text { High } \\
\text { capital } \\
\text { mobility }\end{array}$ \\
\hline \multicolumn{5}{|l|}{ Expenditures on GDP: } \\
\hline GDP, $Y$ & 2.4 & 2.4 & 3.3 & 3.3 \\
\hline Consumption, $C$ & 3.2 & 3.2 & 4.3 & 4.3 \\
\hline Investment, $I$ & 2.4 & 2.4 & 3.3 & 3.3 \\
\hline Government spending, $G$ & 0.0 & 0.0 & 0.0 & 0.0 \\
\hline Exports, $X$ & 1.5 & 1.5 & 2.1 & 2.0 \\
\hline Imports, $M$ & 1.6 & 1.6 & 2.2 & 2.2 \\
\hline \multicolumn{5}{|l|}{ Balance of payments: } \\
\hline Private net inflow, $S_{N F}$ & 0.4 & 0.7 & 0.6 & 0.9 \\
\hline Change in official reserves, $\Delta R$ & 0.0 & 0.0 & 0.0 & 0.0 \\
\hline Current acc. surplus ${ }^{\mathrm{a}}, \Delta(X-M)$, US $\$$ bn & -0.1 & -0.2 & -0.2 & -0.3 \\
\hline \multicolumn{5}{|l|}{ Money supply and interest rate: } \\
\hline Nominal money supply, $M_{S}$ & 0.2 & 0.2 & 1.6 & 1.6 \\
\hline Home interest rate, $r$ & 0.1 & 0.1 & 0.1 & 0.1 \\
\hline \multicolumn{5}{|l|}{ Exchange rate: } \\
\hline Real exchange rate, $e_{R}$ & -1.0 & -1.0 & -1.4 & -1.4 \\
\hline Nominal exchange rate, $E$ & 0.0 & 0.0 & -1.4 & -1.4 \\
\hline \multicolumn{5}{|l|}{ Supply side: } \\
\hline Real wage, $w=W / P$ & 1.0 & 1.0 & 0.0 & 0.0 \\
\hline Nominal wage, $W$ & 0.0 & 0.0 & 0.0 & 0.0 \\
\hline Unemployment rate, $u$ & -20.6 & -20.9 & -48.9 & -48.9 \\
\hline \multicolumn{5}{|l|}{ Price level: } \\
\hline Home price level, $P$ & -1.0 & -1.0 & 0.0 & 0.0 \\
\hline
\end{tabular}

a This is the US\$ change in the current account surplus due to the tabulated shock.

Source: Simulations using the model discussed in the text. 